\title{
Relationships between Export Success, Export Strategies, and Export Planning
}

\author{
Granger Macy \\ Bruce Barringer \\ University of Missouri \\ Columbia, Missouri \\ Max Wortman \\ Iowa State University \\ Ames, Iowa
}

The remarkable pace of change in world markets has caused a fundamental shift in the number of possible avenues of growth for U.S. exporters. Eastern Bloc countries and the republics of the former Soviet Union are actively soliciting trade. Asian economies are experiencing growth at an unprecedented rate. The approaching unification of the European Community and the possibility of a ratified North American Free Trade agreement may provide additional opportunities for well-positioned U.S. firms.

For many U.S. companies, exports represent a small but still vital portion of their overall sales. Exports can also decrease the trade deficit and reduce unemployment. Depending on the source, it has been estimated that each additional billion dollars worth of exports creates between 19,600 and 30,000 new jobs. The Commerce Department, the Department of Labor, and the U.S. Export/Import Bank have made estimates within this range. A deeper understanding of how firms reach their full export potential is important for American businesses and the nation as a whole.

\section{Background}

For many firms, target market selection and product considerations are the main dimensions of their export programs $([3],[5])$. Some U.S. firms, for example, export regionally and may compete primarily on price. Others export across the globe and emphasize customer satisfaction and quality products. Recent developments in the international economy with regard to regional trade agreements such as NAFTA and EC92, and the outcome of the GATT negotiations, will affect all types of exporters.

One key to competing successfully may be the development of complementary product/market strategies. The primary thrust of this paper is to examine the role of planning in this process. Here we examine a specific type of planning we refer to as 'export planning.' It is defined as the development of a distinct export plan and the systematic incorporation of that plan into the firm's annual strategic plan. Firms that practice export planning may be better equipped to develop and execute synergistic export strategies.

Several studies have examined the simple bivariate relationship between export planning and export success. Cooper and Kleinschmidt [5] found that the best per- 
formers among Canadian exporters in the electronics industry conducted the most extensive export planning. Madsen [16] found similar results with Danish manufacturing firms. In addition, Walters and Samiee [26] found a positive relationship between what they called "strategic export planning activities" and export success. To the best of our knowledge, only Walters [25], in a study of the lumber industry, found no relationship between export planning and the relative importance of exporting to the firm. With regard to the success of export strategies, however, planning appears to be a factor that is consistently important.

This study extends existing export success research by examining the importance of export planning to specific product and market aspects of a firm's export strategies. We will examine the interaction between export planning, product/market strategies, and export success. Based upon the existing literature, the strategies most commonly associated with export success are identified and discussed. Hypotheses are then proposed and tested in order to examine the role of export planning in creating sound product/market strategies.

\section{Export Strategy and Export Planning}

The eventual success of any export program may depend on the synergy between its market selection and product strategies. Carefully crafted product/market strategies are not ad hoc events. There is significant support in the literature that conscientious strategic and functional planning improves both the technical and the strategic elements of export plans ([5], [12], [22]). We expect that successful, value building strategies will be structured to best position a company within its relevant market. For exporters, this usually means developing product and market selection strategies that complement each other and deliver maximum value to a highly competitive global marketplace. A market selection strategy should complement a firm's strengths, be consistent with its long term goals and objectives, and ultimately lead to exporting success.

In the following sections we will define and discuss specific elements of export market selection and product strategies. In support of this discussion, we also review key aspects of the relevant literature. This literature is summarized in Table 1. We then examine the role of export planning and present hypotheses describing its place in achieving successful product/market strategies.

\section{Market Selection Strategy}

Market selection strategy refers to the overall company program for selecting foreign markets. Exporters typically adopt a market selection strategy that emphasizes either market diversification (exporting across the globe) or market concentration (exporting to only a few key markets). As shown in Table 1 market diversification has been commonly found to be positively related to export growth and export intensity. Market concentration may be a more deliberate, risk adverse approach. Once a presence in a foreign market has been established, attention may be shifted toward expansion within that market, rather than entering additional markets. Accordingly, steps 
Spring 1993 Macy, et al.,: Relationships between Export Success

Table 1: Summary of Selected Empirical Studies on the Determinants of Export Success

\begin{tabular}{|c|c|c|c|c|c|c|c|c|}
\hline 홀 & 薃 & 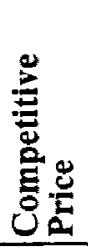 & 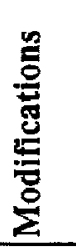 & 急 & 咅 & 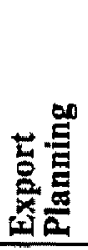 & 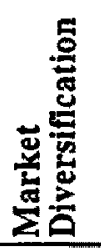 & 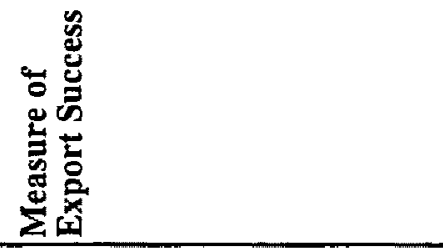 \\
\hline Cavusgil [3] & 1984 & & & + & & & & Degree of Internationalization \\
\hline $\begin{array}{l}\text { Christenson, } \\
\text { et al. [4] }\end{array}$ & 1987 & + & $\begin{array}{l}- \\
+\end{array}$ & $\stackrel{+}{\text { NSS }}$ & & + & NS & $\begin{array}{l}\text { Exporting/No Longer Exp. } \\
\text { Export Intensity }\end{array}$ \\
\hline $\begin{array}{l}\text { Cooper \& } \\
\text { Kleinschmidt [5] }\end{array}$ & 1985 & & + & NS & & & + & Export Growth \\
\hline $\begin{array}{l}\text { Diamanto- } \\
\text { poulos [6] }\end{array}$ & 1988 & - & NS & + & & & + & $\begin{array}{l}\text { Export Intensity } \\
\text { ROI }\end{array}$ \\
\hline $\begin{array}{l}\text { Douglas \& } \\
\text { Craig [7] }\end{array}$ & 1983 & NS & & + & & & & Market Share \\
\hline $\begin{array}{l}\text { Kirplani \& Mac- } \\
\text { Intosh [12] }\end{array}$ & 1980 & - & & & + & & + & $\begin{array}{l}\text { Export Growth } \\
\text { Export Intensity }\end{array}$ \\
\hline Lee \& Yang [13] & 1990 & & & + & & & $\begin{array}{l}+ \\
-\end{array}$ & $\begin{array}{l}\text { Export Growth } \\
\text { Export Profitability } \\
\text { Export Intensity }\end{array}$ \\
\hline Louter [15] & 1991 & NS & NS & + & & + & & $\begin{array}{l}\text { Relative Export Profitability } \\
\text { Export Sales }\end{array}$ \\
\hline Madsen [16] & 1989 & $\stackrel{+}{\mathrm{NS}}$ & $\stackrel{+}{\text { NS }}$ & $\begin{array}{l}+ \\
+\end{array}$ & & + & & $\begin{array}{l}\text { Export Growth } \\
\text { Export Profitability }\end{array}$ \\
\hline Namiki [20] & 1988 & & + & & & & & Export Intensity \\
\hline Rocha, et al. [21] & 1988 & & & + & & + & + & $\begin{array}{l}\text { Aggress. v. Passive Exporters } \\
\text { Export Intensity }\end{array}$ \\
\hline $\begin{array}{l}\text { Samiee \& } \\
\text { Walters [22] }\end{array}$ & 1990 & & & & & & $\stackrel{+}{\text { NSS }}$ & $\begin{array}{l}\text { Market Diversification } \\
\text { Export Profits }\end{array}$ \\
\hline Seifert \& Ford [23] & 1989 & & & & + & & & Satisfaction with Exp. Prog \\
\hline $\begin{array}{l}\text { Suzman \& } \\
\text { Wortzel [24] }\end{array}$ & 1984 & + & & & & & + & Tech. Prof. \& Exp. Strat. Fit \\
\hline Walters [25] & 1985 & & + & & & & $\begin{array}{l}\text { NS } \\
+\end{array}$ & $\begin{array}{l}\text { Relative Importance of Exp. } \\
\text { Export Intensity }\end{array}$ \\
\hline $\begin{array}{l}\text { Walters \& } \\
\text { Samiee [26] }\end{array}$ & 1990 & & & & & & + & Profit \\
\hline
\end{tabular}

$+/-$ direction of significant effect between factor and export success

NS no significant effect 
are taken to widen the local market base and enter new segments [7]. To maximize market share, products are often designed or differentiated specifically for those markets.

Conversely, firms that follow the market diversification approach export to a higher number of countries [13]. By taking a low market share in a large number of countries, these firms can usually avoid direct competition with the major players in each market [21]. As a result, they can generally export a more standardized product as long as product quality meets global standards.

\section{Product Strategies}

Product strategy involves blending different marketing mix elements in order to develop the right product or service for the intended market [1]. Here we conceptualize product strategy in four dimensions; price, quality, modification, and promotion. Developing product and market selection strategies as a cohesive whole should produce more effective strategies. Together, these elements are used to define the basis on which a firm chooses to compete.

Exporters typically follow one of three price strategies: price leadership, price parity (matching local prices in the destination country), or price at the domestic price plus a premium. Cooper and Kleinschmidt [5] found that exporters who establish a price advantage generally fit a fairly narrow profile. They typically export fairly generic products to nearby or convenient markets. This is generally a low cost strategy emphasizing economies of scale. Although some have reported that successful exporters tend to price competitively in their destination countries ([2], [4], [19]), Table 1 shows that the empirical results are mixed. Alternatively, some exporters may consider their products to be unique and choose not to price competitively. Such an approach may yield higher margins but lower market penetration and may account for the weak findings in this area.

In contrast to price, high product quality should be considered a virtual prerequisite for export participation and growth. Table 1 shows many positive relationships between product quality and success across studies. In a study of manufacturing firms, Cavusgil [2] found that exporters don't need a new product to be successful, but the product must be of high quality. Firms that compete on quality typically emphasize some product characteristic that exceeds the norms. This can take on several forms including product style, service level, durability, or technological sophistication.

Product modification is another product strategy. This refers to the practice of designing or customizing products to appeal to specific foreign markets [23]. Like quality, this strategy can take on a number of different dimensions. Product design, packaging, method of delivery, or a customer service developed specifically for a particular market are examples of a product modification strategy.

Modification strategies are typically aimed at building market share within a particular foreign market. As such, product modification is generally associated with a market concentration approach. The empirical studies shown in Table 1 have generally supported the value of product modification in a competitive export strategy. 
However, not all experts agree. Levitt [14] argued against product modification. He stated that simplicity and economies of scale are the key factors, and that globalization of markets should imply standardization of products worldwide. This brings costs down which can potentially expand world markets. Nevertheless, many exporters encourage product modification. A popularaxiom among exporters combines the two approaches, "Standardize what is possible, differentiate where necessary" [15]. Such conflicting viewpoints have yet to be adequately resolved.

The final dimension of export product strategy considered here is promotion. This area is not well researched but tends to be positively related to export success. It is generally believed that most firms invest much less in promotion for export markets than for domestic markets. Exporters may rely on their importers to promote their products once ownership has changed hands. Seifert and Ford [23] asked 65 U.S. exporters from diverse industries about their export promotion budgets. Only $4.5 \%$ of the companies spend proportionally more on exports than domestic products. Firms that did promote their exports typically fell within the market concentration category. Such firms are more able to focus their promotional efforts by concentrating on fewer markets. Promoting products across multiple markets could spread resources too thin and be ineffective within individual markets.

\section{Selection of Product/Market Strategy}

Although we believe that there is no one best export strategy, the empirical literature does suggest that certain combinations of product and market selection strategies are conceptually more reasonable. Competitive pricing is typically associated with the market concentration approach. These firms typically sell a standardized, high volume product to a limited number of markets [18]. A much different but also potentially effective market concentration approach emphasizes product modification. This is a differentiation strategy that is aimed at building market share in selected markets. Product promotion is also associated with building market share in a limited number of markets.

In contrast, the optimal approach for market diversification may be high quality. As discussed previously, there are several paths available to achieve high quality. The importance of quality may be due to the wide market demand for intrinsically appealing products.

\section{Export Planning}

Planning is proposed to be a key antecedent to export success. In this study, export planning is conceptualized as the extent of effort on the part of an exporter to systematically incorporate exporting into the firm's strategic plans. It is analogous to a firm carefully integrating a business strategy into its broader corporate strategies and narrower functional strategies. Such planning helps assure that a firm's export program is consistent with its overall goals, objectives, and internal capabilities.

As mentioned earlier and summarized in Table 1, a relationship between export planning and export success has been supported by previous empirical research. 
Howard and Herremans [9] conducted a subjective study of 273 winners of the Department of Commerce "E" award for excellence in exporting. Each of the firms were asked to evaluate 23 different activities in terms of overall importance to export operations. Planning activities received the highest rankings.

Our purpose was to investigate a more complex relationship that considers export planning, product/market strategies, and export success. Different strategies may require different degrees of rigor in export planning. The next section posits potential relationships between specific product/market strategies, export planning, and export success.

\section{Hypotheses}

Taken together these hypotheses posit that export success may be achieved through one of several complementary product/market strategies. It is not our intention to find some 'ideal' combination of export strategies and planning intensity. Export planning is examined as a potential catalyst in the development of sound export strategies, and specified as a moderating variable in the following hypotheses.

H1a: Competitive pricing will be related to increased export success under conditions of market concentration regardless of the level of export planning.

H1b: Competitive pricing will be related to increased export success under conditions of market diversification and high levels of export planning.

Firms that price their exports competitively typically sell standardized, high volume products designed for manufacturing efficiency. The focus on planning is at home, rather than abroad, so as to support the complexities required to maintain high volume production facilities. Frequently, the same product can be sold domestically and abroad. In this approach, profitability results from the effectiveness of the manufacturing process rather than premium pricing.

The level of export planning should not be critical for firms that match competitive pricing with the market concentration approach. Markets can be selected for stability and minimal risk. Distribution channels can be established and exporting can be managed on a rather routine basis. Conversely, export planning is more critical for firms that match competitive pricing with the market diversification approach. As market diversification increases, the need for market scanning and thus export planning increases. In this situation, competitive pricing is more likely to be successful where higher planning intensity is present to adequately assess market pricing.

Competitive pricing appears most useful for standardized products without any clearly defined product advantage. Noncompetitive pricing is expected to be appropriate where product uniqueness generates the demand. Noncompetitive pricing may require extensive market scanning and careful market selection. Such an approach may create high profitability; but the selectivity of the approach may not necessarily yield high sales levels or a large export market in terms of the number of countries. Since the measures of success in this study do not focus on profitability, a noncompetitive pricing strategy is not likely to be related to the measures of success used in this study. 
H2: High product quality will be related to increased export success under conditions of market diversification regardless of the level of export planning . High product quality has consistently been linked with export success ([15], [16], [17]).

A quality strategy focuses on product strength and technology rather than on low price. A market diversification approach is indicated in that high quality products can penetrate even particularly demanding markets. In addition, Madsen [16] found that exporters of high quality products are more successful in attracting successful agents and distributors. These intermediaries may facilitate reaching additional markets. This may also allow firms to leave their export planning to the intermediaries and concentrate on other product issues. In this case, high product quality may actually be associated with relatively low levels of export planning.

On the other hand, products need to be differentiated to be successful using a quality approach. A company may thus need to keep abreast of consumer preferences and plan to adapt to changing preferences. Thus a quality approach may be successful under either low or high levels of export planning.

H3: Product modification will be related to increased export success under conditions of market concentration and high levels of export planning.

Firms that practice product modification typically select one or more attributes that many buyers in a particular foreign market perceive as important, and position their products to meet those needs. This is typically done in an effort to capture a specific market. Rather than export a general product, the product is modified to accommodate local needs.

As a competitive strategy, product modification may be more effective for firms pursuing a market concentration approach. Logistical problems can exist under a product modification policy due to the need to maintain different versions of the product and to set up multiple, shorter production runs. An effective modification strategy will become increasingly complex as a firm diversifies into a greater number of markets. Thus it may be in the firm's best interest to concentrate on achieving penetration in fewer markets.

Product modification also represents a more deliberate, methodological approach than price leadership or quality differentiation. Export planning is expected to be higher so that firms can monitor local preferences and continue to modify their products accordingly.

H4: Product promotion will be related to increased export success under conditions of market concentration and high levels of export planning.

It was mentioned previously that export product promotion is not well researched. It is expected that traditional promotional strategies such as advertising and point of sale marketing can be used more effectively by firms pursuing a market concentration approach. Promotion across a large number of markets may be impractical. Planning intensity for promotion is expected to be high. Effort, managerial input, and intense monitoring of effectiveness are required to maintain promotional programs. 


\section{Methodology}

\section{Sample}

The data for this study were collected from a survey of Midwest agricultural exporters. The companies were identified by using state export directories. An initial mailing was sent to 281 firms. A total of 151 firms provided usable surveys resulting in a response rate of $54 \%$.

A wide variety of firms were represented in the survey including squipment manufacturers and chemical producers. Agricultural firms were chosen because they are heavily involved in exporting and they include a broad cross section of firms that use various product/market strategies. The typical survey respondent had 10 to 20 years of export experience, employed 50 to 100 people, and exported to 3 continents and 8 different countries. The firms also varied in terms of how much they exported; $41 \%$ export up to $6 \%$ of sales, $34 \%$ export $6-15 \%$ of sales, and $25 \%$ export more than $15 \%$ of sales.

\section{Variables}

The study employed three sets of variables including product strategy, export planning, and export success.

1. Product strategy measures included the four product strategy variables of price, quality, modification, and promotion. These were the anticipated predictors of export success.

The price variable asked respondents to indicate the category that best described how they priced their products for export. This measured whether competitive pricing was used in the destination country. Codes ranged from 0 to 2 with higher numbers representing more competitive pricing.

The modification variable measured the extent to which the firm relied on modifying its products to suit the taste of its foreign markets. This was coded: 0 - no modifications; 1 - minor modifications; 2 - major modifications.

The quality measure asked respondents about the relative quality level of the firm's products as compared to competitors in destination countries. It was coded: 0 - below average; 1 - average; 2 - above average; 3 - quality leader.

The promotion variable measured the extent to which the firm relied on promotion to compete in foreign markets. Promotion was operationalized by asking firms whether their promotional spending for exports was lower; the same as; or higher than their promotional spending for domestic markets. These choices were coded 0 through 2 respectively.

2. Export planning was used as a moderator variable. Each hypothesis was tested under conditions of "low planning" and "high planning." The export planning variable asked respondents to evaluate to what extent the export plan was incorporated into their annual strategic and operating plans. Firms in the "low planning" category reported that there was either no export plan or that their export plan was not incorporated into their annual strategic and operating plans.

3. Export success included two dependent variables; export intensity (total export sales divided by total firm sales) and the number of countries to which products are 
exported. The export intensity variable (EI) measured overall export success. This data was collected in categories with 5\% increments. Thus a code of 1 equates to an export intensity up to $5 \%$; a 2 equates to export intensity up to $10 \%$, and so on. The variable for number of countries (NUCTY) indicated the geographic scope of a firm's export operations and in combination with EI represents a proxy for market selection strategy. It was coded as 1 - up to 5 countries; 2 - 6 to 10 countries; 3 - 11 to 20 countries; 4 - more than 20 countries.

\section{Analysis}

The means and response counts for each variable are presented in Table 2. Note that these data are categorical.

Table 2: Variable Means and Distributions

\begin{tabular}{lrrrcccccccc}
\hline & Mean & 0 & 1 & 2 & 3 & 4 & 5 & 6 & 7 & 8 & 9 \\
\hline Price & 1.18 & 30 & 55 & 56 & & & & & & & \\
Modification & .83 & 44 & 84 & 19 & & & & & & & \\
Quality & 2.21 & 1 & 23 & 66 & 57 & & & & & & \\
Promotion & .51 & 87 & 50 & 13 & & & & & & & \\
Export Planning & .77 & 34 & 117 & & & & & & & & \\
Export Intensity & 2.46 & & 61 & 41 & 11 & 17 & 12 & 2 & 2 & 3 & 2 \\
Number Countries & 1.83 & & 82 & 28 & 22 & 17 & & & & & \\
\hline
\end{tabular}

The distributions of export intensity and NUCTY, the dependent variables, are not normally distributed. This is consistent with other export success studies [1]. Normally, many of the commonly applied linear tests are robust to non-normal dependent variables. However, in this case, there is a very high level of non-normality. As a result, the study employed techniques designed to offset this difficulty.

First, a Spearman rank order correlation matrix was used. This is appropriate for ordered categorical data. These correlations are used to show population wide associations. Second, logit analysis, a multivariate test, was used to analyze the hypotheses. This form of regression is appropriate for categorical data and is used extensively in evaluating dichotomous dependent variables. To utilize this approach, the dependent variables were reduced to dichotomous categories. All export intensities (EI) above the lowest response were combined into one category. The same was done for number of countries (NUCTY). This reduced each of the dependent variables into two categories of relatively balanced size representing a low and high level for each variable. The moderator variable, export planning (EP), was then used to partition the data into firms representing "low" and "high" levels of export planning. Logistic regression was then applied to each dependent variable twice, once for each level of EP. 
Following this, matching models were computed using ordinary least squares regression. These tests were conducted for comparison to the logit analysis. In this case, the original data was used for the dependent variables; i.e., no dichotomous categorization. If these results were found to be reasonably consistent, then it could be concluded that little information was lost by combining the dependent variables into categories for hypothesis testing.

\section{Results}

The Spearman rank order correlations are shown in Table 3. Consistent with previous studies, export planning (EP) was found to have a high positive correlation with both dependent variables, export intensity (EI) and number of countries (NUCTY).

\section{Table 3: Spearman Rank Order Correlations}

\begin{tabular}{lcccccc}
\hline & 1 & 2 & 3 & 4 & 5 & 6 \\
\hline Price & & & & & & \\
Modification & $.181^{*}$ & & & & & \\
Quality & .108 & .147 & & & & \\
Promotion & -.107 & .066 & .109 & & & \\
Export Planning & .132 & $.273^{* *}$ & .119 & $.206^{*}$ & & \\
Export Intensity & .090 & $.263^{* *}$ & .215 & $.393^{* *}$ & $.239^{* *}$ & \\
Number Countries & $.196^{*}$ & $.156^{*}$ & $.378^{* *}$ & $-.041^{* *}$ & $.303^{* *}$ & $.306^{* *}$ \\
\hline
\end{tabular}

${ }^{*} \mathrm{p}=<.05$

${ }^{* *} \mathrm{p}=<.01$

The results of the logit analysis are shown in Table 4. The logistic regression coefficients are difficult to interpret due to logarithmic transformations, and thus the raw coefficients are not reported.

Table 4: Logistic Regression Chi-Square Test of Significance

\begin{tabular}{lcrrr}
\hline Strategy & \multicolumn{2}{c}{ EI } & \multicolumn{2}{c}{ NUCTY } \\
& EP=0 & EP=1 & EP=0 & EP=1 \\
\hline Total Model & ns & $* * *$ & $* *$ & $* * *$ \\
Price & & ns & $* * *$ & $*$ \\
Modification & & $* *$ & ns & ns \\
Quality & & ns & $* *$ & $* * *$ \\
Promotion & & $* * *$ & $* * *$ & ns
\end{tabular}

\footnotetext{
* $\mathrm{p}=<.10$

** $\mathrm{p}=<.05$

$* * * p=<.01$
} 
This table presents the differences between low levels and high levels of planning on each of the four product variables. This is shown for each dependent variable; export intensity (EI) which is the measure of overall export success and the number of countries (NUCTY) which is a measure of the achievement of market diversification. The results shown in this table largely support the central premise of this study; i.e., export planning differentially affects the success of product/market strategies.

The ordinary least squares (OLS) results are presented in Table 5. These results attest to the robustness of the OLS procedure. All tests of significance between the logit analysis and OLS agreed except for pricing and number of countries under the low planning condition. Furthermore, only one coefficient, indicated in Table 5, did not agree as to the direction of the effect; and this coefficient was not significant in either analysis.

\section{Table 5: Ordinary Least Squares Regression Coefficients}

\begin{tabular}{lcccc}
\hline Strategy & \multicolumn{2}{c}{ EI } & \multicolumn{2}{c}{ NUCTY } \\
& $\mathrm{EP}=0$ & $\mathrm{EP}=1$ & $\mathrm{EP}=0$ & $\mathrm{EP}=1$ \\
\hline Price & -.01 & .05 & -.14 & $.16^{*}$ \\
Modification & .04 & $.53^{*}$ & .11 & .03 \\
Quality & .31 & .12 & $.19^{*}$ & $.20^{*}$ \\
Promotion & $.23 \mathrm{c}$ & $.68^{*}$ & $-.24^{*}$ & -.07 \\
\hline
\end{tabular}

*indicates significance in both logit and OLS techniques

c indicates sign change between logit and OLS techniques

\section{Evaluation of Hypotheses}

All hypotheses were evaluated with respect to the logit results shown in Table 4. The effect of pricing strategy as proposed in Hypothesis 1a was not supported. Pricing had no significant effect on export intensity. However, Hypothesis $1 \mathrm{~b}$ was supported in that competitive pricing exhibited a positive effect on number of countries (NUCTY) under high planning. In Table 5 note the difference in the effect of competitive pricing between levels of planning for NUCTY. This is a clear indication of the effectiveness of planning in a market diversification strategy. Under high planning there was a positive relationship significant in both the OLS and logistic regressions. Under low planning, there was an inverse relationship that was significant in the logistic regression.

Hypothesis 2 was accepted. Quality had a significant positive relationship only with NUCTY and this occurred regardless of the level of planning. These results were uniformly significant across both regressions in Tables 4 and 5 . This supports the importance of quality to a market diversification strategy.

Hypothesis 3 was also supported. Modification was significant for export intensity (EI) under high export planning but was not significant for number of countries. Again, this result was consistent in both regression procedures. 
Hypothesis 4 was accepted. Product promotion was significantly and positively related to EI under high planning but inversely related to NUCTY with similar results found in both the OLS and logistic regression. This strongly indicates the importance of market concentration to the success of promotional activities.

\section{Discussion}

The findings of this study demonstrate that the effectiveness of certain export product/market strategies are strongly related to the firm's level of export planning. Recall that export planning is a specific type of planning. It was defined as the development of a distinct export plan and the systematic incorporation of that plan into the firm's annual strategic plan. Previous studies had established a simple bivariate relationship between export planning and export success. This study has demonstrated one important reason why export planning contributes to export success. Apparently, firms that practice export planning are able to develop more complementary product/ market strategies. For example, export intensity (EI) was influenced by product modification and promotion, but only when accompanied by high levels of export planning. Low planners were not able to execute these strategies with as much success.

Different patterns emerged for the dependent variable, number of countries (NUCTY). To the best of our knowledge, this has only been utilized once as a dependent variable in previous export success studies. NUCTY actually has a dual impact, both as a dependent and an independent factor. In one sense, it represents a firm's deliberate selection of countries; yet, the firm must also be successful in those markets to remain in them. The results of this may be especially useful as exporters contemplate entering new markets. NUCTY was related to competitive pricing, promotion, and product quality. The finding of the effectiveness of competitive pricing under conditions of high planning was not unexpected. Although this hasn't been examined previously, it is contrary to suggestions in much of the export success literature. The relationship between NUCTY and quality replicates previous studies. Apparently high product quality is associated with export success in this context regardless of the level of planning. The inverse relationship between NUCTY and product promotion under low export planning is also noteworthy. Promotional spending appears to have limited usefulness in penetrating a large number of markets.

The results for quality require additional comment. Only one firm reported its quality as zero, or "below average." There are different ways to explain this. First, these companies are all exporters. Exporters may be expected to represent a biased frame of above average producers. Second, the respondents may have been reluctant to assess their products as low quality. This would reflect an inherent limitation of self-assessed measures. The first problem would result in a 'restriction of range' while the second could be considered 'noise' in the data. Such problems limit the ability of statistical tests to detect a significant effect. Nevertheless, there were still clear relative rankings among the firms and the statistical tests for quality were significant. 
It would thus appear that the effect of quality is quite strong; enough to be detected regardless of the source of the skewed response.

Although there was a significant relationship between quality and number of countries, the relationship between quality and export intensity was not significant. This finding is counter to previous studies which have generally found a positive relationship between quality and measures of export success. However, caution should be exercised in interpreting this result. This result may be an artifact of the methodological issues just discussed rather than the actual contribution of product quality. On the other hand, the correlations reported in Table 2 between quality and export intensity were significant and consistent with previous studies. It thus seems more likely that this data is actually similar to other studies. Perhaps the data in other studies were also skewed but were simply not examined for this problem. Perhaps a more important reason for this lack of significance is that the control for other dimensions of product strategy provides a more accurate representation of the true relationship. Further research is needed to resolve this dilemma.

One suggestion for dealing with the limitation of the quality variable in future research would be to use multiple item scales to assess product quality. Garvin [8], for example, proposed that product quality can be captured in eight dimensions. Another suggestion is to use at least a seven point scale. Operationalizing quality consistent with these suggestions may help to reduce respondent resistance and broaden the range of responses.

The analyses also revealed some important patterns regarding export planning and the product variables. Planning was important to product modification and promotion strategies as expected. Earlier it was argued that these product strategies require high levels of planning because of the managerial input and process complexities involved. With or without planning it is also clear that quality is the primary means for achieving success in a market diversification strategy.

On the other hand, promotion appears to be a relevant strategy for market penetration but not market diversification. This can be seen in its differing effects of promotion on export intensity and number of countries. Under low levels of planning, there was a significant negative relationship between product promotion and the number of countries exported to. This is an important result. As proposed in hypothesis 4 , it suggests that firms pursuing geographic dispersion in their export programs are actually hindered by channeling resources into product promotion. Alternately, promotion contributed to export intensity under high planning; a seemingly contrary finding. This suggests that promotion can be effective as long the market breadth is not large. Thus the success of a promotional strategy appears to be highly dependent on the overall fit of the strategy.

\section{Conclusions}

This study has examined complex relationships between three crucial export variables; market selection strategy, product strategy, and export planning. It has supported 
the premise that export planning plays an important role in the development of complementary product/market strategies. Product/market strategies that are not complementary may not be viable in an increasingly competitive global marketplace. While past research has convincingly supported the relationship between export planning and export success, the specific contribution of export planning had received minimal attention. We have offered an critical first step in a promising line of inquiry.

Unlike many previous studies investigating bivariate relationships replicated in other export studies, our study has revealed the importance of planning to the effectiveness of many strategies, most notably pricing and quality. Results of this study help to increase our understanding of the complexity in crafting a successful export strategy and give more detailed guidance to managers attempting to determine the steps necessary to increase their export performance.

Several specific guidelines emerge that may be of particular interest to active and would-be exporters. First, product quality and competitive pricing are important for achieving market diversification. Market diversification is a relatively aggressive strategy that must be complemented by a favorable product and price to facilitate continued entry into new markets. Second, product modification and promotion are important for increasing exports overall. These strategies may particularly appeal to firms trying to build market share in selected markets. Finally, export planning is an important component to export success. Defined here as the systematic incorporation of exporting into a firm's strategic plans, export planning apparently helps to equip managers to formulate effective export strategies.

This study has also shown that successful export strategies are situationally determined by many factors. Research should continue to explore the relationships of other factors which may impact on export success. Other factors are likely to influence the optimal strategy for companies to pursue. Such elements as firm size and specific elements of non price competition, if researched, could help to understand other situational factors likely to effect export success.

\section{References}

1. Boone, L.E. and Kurtz, D.L. Contemporary Marketing. Chicago: Dryden (1986).

2. Cavusgil, S.T. "Differences Among Exporting Firms Based on Their Degree of Internationalization." Joumal of Business Research, Vol. 12 (1984), pp. 195-208.

3. Cavusgil, S.T. and Naor, J. "Firm and Management Characteristics as Discriminators of Export Marketing Activity." Journal of Business Research, Vol. 15, No. 3 (1987), pp. 221-232.

4. Christensen, C.H., Rocha, A. \& Gertner, R.K. "An Empirical Investigation of the Factors Influencing Exporting Success of Brazilian Firms." Journal of International Business Studies, Vol. 18, No. 3 (1987), pp. 61-77. 
5. Cooper, R.G. and Kleinschmidt, E.J. "The Impact of Export Strategy on Export Sales Performance." Journal of International Business Studies, Vol. 16, No. 1 (1986), pp. 3754.

6. Dianantopoulos, A. "Identifying Differences Between High- and Low-Involvement Exporters." International Marketing Review, Vol. 5, No. 2 (1988), pp. 52-59.

7. Douglas, S.P. and Craig, S.C. "Evaluation of Global Marketing Strategy." Columbia Joumal of World Business, (Fall 1989), pp. 47-59.

8. Garvin, D.A. "Quality on the Line." Harvard Business Review, Vol. 61 (SeptemberOctober 1983), pp. 65-73.

9. Howard, D.G. and Herremans, I.M. "Sources of Assistance for Small Business Exporters: Advice from Successful Firms." Joumal of Small Business Management, Vol, 26, No. 3 (1988), pp. 48-54.

10. Johnson, W.J. and Czinkota, M.R. "Export Attitudes of Industrial Manufacturers." Industrial Marketing Management, Vol. 14 (1985), pp. 123-132.

11. Kathawala, Y., Judd, R., Monipallil, M., and Weinrich, M. "Exporting Practices and Problems of Illinois Firms." Journal of Small Business Management, Vol. 27, No. 1 (1989), pp. 53-58.

12. Kedia, B.L and Chhokar, J. "Factors Inhibiting Export Performance of Firms: An Empirical Investigation." Management International Review, Vol. 26, No. 4 (1986), pp. 3343.

13. Lee, C.S. and Yang, Y.S. "Impact of Export Market Expansion Strategy on Export Performance." International Marketing Review, Vol. 7, No. 4 (1990), pp. 41-50.

14. Levitt, T. "The Globalization of Markets." Harvard Business Review, Vol. 61, No. 3 (1983), pp. 92-102.

15. Louter, P.J., Ouwerkerk, Cok and Bakker, Ben A. "An Inquiry into Successful Exporting." European Journal of Marketing, Vol. 25, No. 6 (1991), pp. 7-23.

16. Madsen, T.K. "Successful Export Marketing Management: Some Empirical Evidence." International Marketing Review, Vol. 6, No. 4 (1989), pp. 41-57.

17. McGuinness, N.W. \& Little, B. "The Influence of Product Characteristics on the Export Performance of New Industrial Products." Journal of Marketing, Vol. 45, No. 2 (1981), pp. 110-122.

18. Miller, D. "Relating Porter's Business Strategies to Environment and Structure: Analysis and Performance Implications." Academy of Management Journal, Vol. 31, No. 2 (1988), pp. 280-308. 
19. Moon, J. and Lee, H. "On the Internal Correlates of Export Stage Development: An Empirical Investigation in the Korean Electronics Industry." International Marketing Review, Vol. 7, No. 5 (1990), pp. 16-26.

20. Namiki, N. "The Impact of Competitive Strategy on Export Sales Performance: An Exploratory Study." The Mid Atlantic Journal of Business, Vol. 25, No. 6 (1989), pp. 21-37.

21. Rocha, A. da, Christensen, C.H. and Eduardo, Eduardo da Cunha, C. "Aggressive and Passive Exporters: A Study in the Brazilian Furniture Industry." International Marketing Review, Vol. 7, No. 5 (1990), pp. 6-15.

22. Samiee, S. and Walters, P.G.P. "Influence of Firm Size on Export Planning and Performance." Joumal of Business Research, Vol. 20 (1990), pp. 235-247.

23. Seifert, B. and Ford, J. "Are Exporting Firms Modifying Their Products, Pricing and Promotion Policies?" International Marketing Review, Vol. 6, No. 4 (1989), pp. 53-69.

24. Suzman, C.L. and Wortzel, L.H. "Technology Profiles and Export Marketing Strategies." Journal of Business Research, Vol. 12 (1984), pp. 221-235.

25. Walters, P.G. "A Study- of Planning for Export Operations." International Marketing Review, Vol. 2, No. 3 (1985), pp. 74-81.

26. Walters, P.G.P. and Samiee, S. "A Model for Assessing Performance in Small U.S. Exporting Firms." Entrepreneurship Theory \& Practice, Vol. 15, No. 2 (1990), pp. 3350 . 